\title{
BUILDERS OF THE FUTURE
}

\section{The image of an Uzbek woman in Zulfiyakhanim's poems}

\author{
Tursunbayeva Iroda Komiljon qizi \\ Student of Nukus State Pedagogical Institute, Uzbekistan \\ DOI - https://doi.org/10.37547/builders-08
}

\begin{abstract}
The memory of the People's Poet of Uzbekistan, the beloved daughter of the Uzbek people Zulfiyakhanim Israilova lives forever in the heart of every Uzbek. Today, a lot of work is being done in our country to immortalize the memory of Zulfiya Khanum. This year, the 106th anniversary of the poet is celebrated in all educational institutions. The main reason why Zulfiyakhanim's poems are still loved and read is that the pure, sincere feelings in her poems can penetrate and affect any heart. Especially in her unique works, the image of a real Uzbek woman is embodied.
\end{abstract}

KEYWORDS : Zulfiyakhanim's poems, Uzbek women.

\section{INTRODUCTION}

Zulfiyakhanim Isroilova is the wife of the famous Uzbek poet, publicist and statesman Hamid Olimjon. They were both poets. The sincere love of two souls is reflected in his poems. Unfortunately, their happy marriage did not last long. Hamid Olimjon died in a car accident in 1944 at the age of 35. The same young poetess became a widow at the age of 29. This event marked a turning point in the life of the poet, not only in his life but also in his poetry.

Say goodbye to this friend, unfortunately, May your light never go out, may you live among us, In the living heart, say that the friend will never die,

Open your eyes, friends, mourn today, How many dreams, hopes, aspirations, dreams have disappeared, He cried with all his heart, and his friend left.

Through the poem "Marcia" above, the poet expressed his inner feelings at the time of his wife's death.

The poetess dedicates her later life to the upbringing of her children. It is known from history that to this day, this life tests many women with the pain of separation. 


\section{BUILDERS OF THE FUTURE}

If we consider it as a difficult test of life, some people have passed this test, and some have not. It should be noted that Zulfiyakhanim overcame these challenges with perseverance and patience. After the death of her husband, she raised two children alone.

O my child, my eyes are bright,

Who can be like you to me?

You are my life, when I see you,

My heart is full of love.

Through the above poem of the poet "My child" it is possible to understand that she is not only a faithful companion, but also a loving mother. In order to raise an only child, a woman needs a lot of perseverance and patience. Zulfiyakhanim Isroilova did an excellent job.

Zulfiyakhanum also made a great contribution to the eternal life of Hamid Olimjon's memory. Through his poems, the poet described his love and devotion to the land. His work caused the rise not only of himself, but also of Hamid Alimjan. The main reason for this is that the poet dedicated his poems to the memory of Hamid Olimjon. As you read the poems of the poet, it is natural that you are interested in whom such pure love and devotion are dedicated. This will encourage you to get acquainted with the life and work of Hamid Alimjan. That is why the memory of Hamid Olimjon lives forever in the poems of Zulfiyakhanim.

Hijra is in my pocket, your word is in my hand

I sing life, the pain of retreat.

You dream at night, I remember the day,

As long as I live, you live too!

The Uzbek people do not love Zulfiyakhan in vain. The main reason why her memory will live forever in every heart is that the real Uzbek woman is depicted in all her qualities in the image of the poet. Therefore, today there is no house among our people without his poems. Every Uzbek guy deserves a place like Zulfiyakhanim. And we, as "followers of Zulfiyakhanim", must work to perpetuate his great memory. People's Poet of Uzbekistan Abdulla Aripov praises women like Zulfiyakhanim and writes:

It even adds to the ornamentation,

Put a statue, too, is a fantasy.

If not in the world,

It would not be so respectable Woman! 


\section{BUILDERS OF THE FUTURE}

\section{REFERENCES}

1. Zulfiya "Spring has come to interrogate you" "Yangi asr avlodi" publishing house2016

2. Zulfiya "Soz chamani-Zulfiya" "Akademnashr" -2020

3. Abdulla Oripov "Poems" Alisher Navoi National Library of Uzbekistan-2016 